\title{
Application of a ground-based microwave radiometer in aviation weather forecasting in Indian Air Force
}

\author{
Savitesh MISHRA ${ }^{1}$, Shreya PANDIT ${ }^{1 *}$, Ashish MITTAL $^{1}$ and Velampudi Sudarshan SRINIVAS ${ }^{2}$ \\ ${ }^{1}$ Air Force Centre for Numerical Weather Prediction, New Delhi 110003, India. \\ ${ }^{2}$ Directorate of Meteorology, Indian Air Force, New Delhi 110003, India. \\ *Corresponding author; email: varsha.23@gov.in
}

Received: September 28, 2020; accepted: March 24, 2021

\begin{abstract}
RESUMEN
El pronóstico específico en tiempo e intensidad, a muy corto plazo o inmediato, es el mayor reto al que se enfrenta un meteorólogo aeronáutico. El radiómetro de microondas terrestre (MWR, por sus siglas en inglés) se ha utilizado para realizar predicciones inmediatas de la actividad convectiva y se determinó que existe una buena comparación entre los parámetros termodinámicos derivados del MWR y las observaciones de radiosondas GPS, lo que indica que las observaciones realizadas con el MWR se pueden utilizar para desarrollar técnicas de predicción inmediata de condiciones convectivas severas. En este estudio se busca resaltar la eficacia de MWR en tormentas eléctricas y niebla de pronóstico inmediato. En primer lugar, las observaciones del MWR ubicadas en Palam, Nueva Delhi, India, se han comparado con los datos de la radiosonda más cercana para determinar la variación en los perfiles respectivos. Se encontraron grandes diferencias en la humedad relativa $(\mathrm{RH})$, mientras que las temperaturas del MWR se encontraron cercanas a la temperatura de radiosonda observada hasta $3.5 \mathrm{~km}$. Posteriormente, los gráficos de dispersión y el coeficiente de correlación de los índices/parámetros termodinámicos indicaron que la mayoría de los parámetros no están correlacionados o tienen una correlación moderada sólo para los perfiles a las 12:00 UTC. La técnica superepoch de composición rezagada para varios índices/parámetros termodinámicos para obtener una imagen combinada de todos los casos de tormenta y niebla densa en la serie de tiempo no pudo determinar ningún patrón para predecir tormentas y niebla densa con un tiempo de espera de 2-4 h. Se analizó el perfil del MWR para un caso de ocurrencia de tormenta. No se observó una variación significativa en la mayoría de los índices (calculados a partir de los parámetros observados con el MWR) antes de que ocurriera la tormenta. La HR a nivel de congelación y entre 950 y $700 \mathrm{hPa}$ fueron los únicos parámetros que aumentaron $4 \mathrm{~h}$ antes de la ocurrencia.
\end{abstract}

\begin{abstract}
Time and intensity-specific very short-term forecasting or nowcasting is the biggest challenge faced by an aviation meteorologist. Ground-based microwave radiometer (MWR) has been used for nowcasting convective activity and it was established that there is a good comparison between thermodynamic parameters derived from MWR and GPS radiosonde observations, indicating that MWR observations can be used to develop techniques for nowcasting severe convective activity. In this study, efforts have been made to bring out the efficacy of MWR in nowcasting thunderstorms and fog. Firstly, the observations of MWR located at Palam, New Delhi, India have been compared with the nearest radiosonde data to ascertain the variation in respective profiles. Large differences were found in relative humidity $(\mathrm{RH})$, whereas temperatures from MWR were found to be close to radiosonde observed temperature up to $3.5 \mathrm{~km}$. Subsequently, the scatter plots and correlation coefficients of thermodynamic indices/parameters indicated that most of the parameters are either not correlated or have moderate correlation only for 12:00 UTC profiles. The superepoch technique of lagged composite for various thermodynamic indices/parameters to obtain a combined picture of all the thunderstorm and dense fog cases on the time series could not determine any pattern to predict thunderstorm and dense
\end{abstract}


fog with lead time of 2-4 hours. MWR profile for a case of occurrence of thunderstorm was analyzed. No significant variation was observed in most of the indices (as calculated from MWR observed parameters) prior to the occurrence of thunderstorm. RH at freezing level and between 950 and $700 \mathrm{hPa}$ levels were the only parameters, which increased four hours prior to the occurrence.

Keywords: radiosonde, microwave radiometer, nowcasting, superepoch analysis.

\section{Introduction}

\subsection{Radiosonde and need of real time profiling}

Information about the vertical atmospheric profile plays an important role in weather prediction. Radiosondes have been some of the most reliable means of retrieving these profiles. It is common practice to examine the temperature and humidity profiles measured by radiosonde and its derived thermodynamic indices/parameters in nowcasting convective weather events. Meteorologists have estimated the wind gust based on temperature, humidity and wind measurements (Lee, 2007). However, radiosonde profiles are discrete in nature and are available twice a day in general. On the other hand, weather instances are due to continuous changes in the atmosphere and these changes are more dynamic in pre-monsoon season, especially in tropical region. This necessitates the use of an equipment capable of continuous profiling to support nowcasting. MWR provides vertical profile of the atmosphere high temporal resolution. The ground-based microwave radiometer (MWR) is a passive sensor that provides continuous atmospheric profile from surface to $10 \mathrm{~km}$. It measures the radiation intensity at different frequencies in the microwave spectrum, which are dominated by the absorption/emission of atmospheric water vapor, cloud liquid water and oxygen (Rose et al., 2003).

\subsection{Earlier studies using MWR}

As per Leena et al. (2015), analysis of MWR-measured temperature (specific humidity) has a warm (wet) bias below $3 \mathrm{~km}$ and cold (dry) bias above that altitude. However, correlation of stability indices estimated from radiometers and radiosondes showed fairly good correlation, with a correlation coefficient greater than 0.5 with $95 \%$ significance. Madineni et al. (2013) studied MWR profile over Indian region and depicted that MWR observations show warm (cold) bias in the temperature, except at $0.5 \mathrm{~km}$, when compared to radiosonde observations below (above) 3-4 km, assuming latter as a standard technique. In case of water vapor, MWR observations show wet (dry) bias below (above) $2-3 \mathrm{~km}$ depending on the time. Venkat et al. (2013) reported warm (cold) bias in temperature below (above) a 3-4 km height when compared with radiosonde measurements. They also noticed a wet (dry) bias in specific humidity for 6-8 $\mathrm{g} \mathrm{kg}^{-1}$ below (above) 2-3 km. Chan (2009) brought out that MWR does not cater for the scattering effects of rain in the given frequency and hence it must be used with caution during the actual occurrence of precipitation.

\subsection{MWR in the Indian Air Force}

The Indian Air Force (IAF) is in possession of 21 MWRs evenly distributed across the country. These are MP-3000A series passive radiometers, which provide continuous thermodynamic profile of the planetary boundary layer (PBL) and above up to $10 \mathrm{~km}$. The equipment measures brightness temperature in both water vapor and oxygen bands and produces atmospheric sounding similar to that of radiosonde every minute. The system scans $21 \mathrm{~K}$-band frequencies (22-30 GHz) and $14 \mathrm{~V}$-band frequencies $(50-59 \mathrm{GHz})$, which are dominated by absorption of water vapor and oxygen molecules, respectively. Retrievals are broadly classified into two domains, i.e., zenith and off-zenith $\left(20^{\circ}\right)$ to mitigate heavy precipitation. The intensities thus received are converted to temperature and moisture profiles by applying the Radiative Transfer Equation (RTE), historical soundings of nearby station and artificial neural network.

\subsection{Nowcasting with MWR}

In the field of aviation, thunderstorms and dense fog are considered as most dangerous aviation weather hazards. Historically, very short-range forecasting of convective weather incidents were based on the extrapolation of radar reflectivity echo. However, the accuracy of these predictions decreases very rapidly in first $30 \mathrm{~min}$ because of short life span of convective cells. For forecasts periods beyond 
$20 \mathrm{~min}$, techniques for predicting the initiation, growth and dissipation of convective storms are essential (Hering et al., 2004). Similarly, significant changes occurring within the PBL are most important to be trapped to predict the occurrence or dissipation of dense fog. MWR has the advantage of continuous monitoring of atmosphere and can play an important role in nowcasting these events. A comprehensive study by Chan (2009) discussed the importance of MWR profile in nowcasting of intense convective weather over Hong Kong. Later (Chan, 2009), he elaborated the importance of MWR derived indices and their usage in nowcasting by correlating derived variables with the lightning activity. Madhulatha et al. (2013) presented the superepoch analysis to bring out the changes in various thermodynamics indices in pre-convective environment.

\subsection{Thermodynamic indices of $M W R$ and radiosonde} Thermodynamic indices are considered as predictors for forecasting aviation weather hazards. The thresholds values of indices calculated from radiosonde observations may not be the same as calculated with the MWR profiles, as both equipments have different working principles. MWR data is to be validated against the nearest radiosonde profile to understand the degree of variation. This paper presents validation of profiles of the MWR installed at Palam, New Delhi, India, vis-à-vis the nearest radiosonde station of India Meteorological Department (IMD) at Safdarjung, New Delhi. Efforts have also been made to study the correlation between the various thermodynamic indices generated by MWR and radiosonde data sets. These indices have been studied further on the temporal scale to bring out the usage of MWR in nowcasting thunderstorm and fog events over Delhi.

\section{Instrumentation and methodology}

2.1 Instrumentation over the area of experimentation

\subsubsection{Palam radiometer}

The radiometer installed at Palam $\left(28.5^{\circ} \mathrm{N}, 77.1^{\circ} \mathrm{E}\right.$, 237 masl), Delhi measures radiation intensity at water vapor (22-30 GHz) and oxygen channel (50-59 GHz) to obtain the temperature and humidity profile. MWR generates profiles every $2 \mathrm{~min}$ with $50 \mathrm{~m}$ vertical resolution up to $0.5 \mathrm{~km}, 100 \mathrm{~m}$ resolution from 0.5 to
$2 \mathrm{~km}$ and $250 \mathrm{~m}$ resolution from 2 to $10 \mathrm{~km}$. A total of three retrievals are available for a given time period, i.e., one zenith and two off-zeniths on either side at a $20^{\circ}$ angle. An average of all the three profiles for each time frame is also made available to the users. However, for the present study only the zenith scan has been utilized. Retrieval of temperature and humidity profiles from radiation intensity is done by applying RTE and artificial neural networks to historical sounding data. The accuracy of temperature and RH sensor of MP-3000A series radiometer is claimed to be $0.5^{\circ} \mathrm{K}$ and $2 \%$, respectively, which is at par with radiosonde observations.

\subsubsection{India Meteorological Department radiosonde} Radiosonde data of the nearest India IMD observation station, Safdarjung $\left(28.5^{\circ} \mathrm{N}, 77.2^{\circ} \mathrm{E}, 216\right.$ masl, Delhi, is used as the base profile to carry out the comparative study. The observations are available twice (00:00 and 12:00 UTC) daily. Both the profiles have been studied separately in this paper for eight cases of thunderstorm and three cases of dense fog events over Delhi. Occurrence, cessation and variation in the intensity of weather events were studied through half hourly aerodrome routine meteorological reports (METAR). Convective events were further substantiated by a Lightning Detection System (LDS) of IAF, a Doppler Weather Radar (DWR) at the Indira Gandhi International Airport (IGI), Delhi and INSAT-3D IR1 images of the relevant time period. Various cases of the significant weather events considered in the present study are shown in Table I.

Table I. Cases of occurrence of thunderstorms and fog.

\begin{tabular}{ccc}
\hline No. & Type of event & Date \\
\hline 1 & Thunderstorm & 07 May 2018 \\
2 & Thunderstorm & 27 Jun 2018 \\
3 & Thunderstorm & 22 Jul 2018 \\
4 & Thunderstorm & 26 Jul 2018 \\
5 & Thunderstorm & 06 Sep 2018 \\
6 & Thunderstorm & 08 Sep 2018 \\
7 & Thunderstorm & 22 Jan 2019 \\
8 & Thunderstorm & 07 Feb 2019 \\
9 & Fog & 01 Jan 2018 \\
10 & Fog & 06 Jan 2018 \\
11 & Fog & 29 Jan 2018 \\
\hline
\end{tabular}




\subsection{Methodology}

In the first part of this study, validation of MWR data is undertaken with the nearest radiosonde profile. Thereafter, a total of nine parameters were studied to bring out the correlation between both the derived profiles: $\mathrm{K}$-Index $\left(\mathrm{KI}\right.$, in $\left.{ }^{\circ} \mathrm{C}\right)$; Total Totals Index (TTI, in ${ }^{\circ} \mathrm{C}$ ); Vertical Total Totals Index (VTT, in ${ }^{\circ} \mathrm{C}$ ); Cross Total Totals Index $\left(\mathrm{CTT}\right.$, in $\left.{ }^{\circ} \mathrm{C}\right)$; MEAN RH (950-700 hPa, in \%); RH at freezing level (FL, in \%); TEMP_DIFF (950-700 hPa, in $\left.{ }^{\circ} \mathrm{C}\right)$; TEMP_DIFF (700-400 $\mathrm{hPa}$, in $\left.{ }^{\circ} \mathrm{C}\right)$, and TEMP_DIFF ${ }^{-}(400-$ $300 \mathrm{hPa}$, in ${ }^{\circ} \mathrm{C}$ ). P value for each set of indices has been calculated using t-test to bring out the probability of variation between datasets.

$\mathrm{KI}$ is a measure of thunderstorm potential based on the vertical temperature lapse rate, and the amount and vertical extent of low-level moisture in the atmosphere, calculated as $\mathrm{KI}=\mathrm{T}(850 \mathrm{hPa})+\mathrm{Td}(850 \mathrm{hPa})$ - T(500 hPa $)-\mathrm{DD}(700 \mathrm{hPa}) \times \mathrm{VTT}$, represents static stability or the lapse rate between 850 and $500 \mathrm{hPa}$, calculated as VTT $=\mathrm{T}(850 \mathrm{hPa})-\mathrm{T}(500 \mathrm{hPa})$. Whereas CTT includes the $850 \mathrm{hPa}$ dewpoint and is represented as $\mathrm{CT}=\mathrm{Td}(850 \mathrm{hPa})-\mathrm{T}(500 \mathrm{hPa})$. The Total Totals Index consists of two components, vertical totals (VTT) and cross totals (CTT). As a result, TTI accounts for both static stability and 850 $\mathrm{mb}$ moisture but would be unrepresentative in situations where the low-level moisture resides below the $850 \mathrm{mb}$ level. TTI can be calculated as TTI $=$ VTT + CTT. Mean RH between $950-700 \mathrm{hPa}$ and at freezing level (RH_FL), along-with temperature differences at three distinct levels, was calculated to derive the moisture availability and lapse rate in the atmosphere. Last part of the study deals with plotting and studying the temporal variation of stability indices in pre-convective environment. The superepoch analysis is carried out with the aim to comment upon the utility of these indices in nowcasting thunderstorm and dense fog events over Delhi.

\section{Results and discussion}

\subsection{Validation of MWR profile using radiosonde data}

3.1.1 Comparison of 00:00 and 12:00 UTC profiles Temperature and RH profiles of MWR and nearest radiosonde (Safdarjung, Delhi) observations have been compared for all the 11 cases. Mean profiles of the MWR zenith scan for 00:00 and 12:00 UTC and radiosonde are shown in Figures 1 and 2, respectively, where the Y-axis depicts altitude of the comparison in
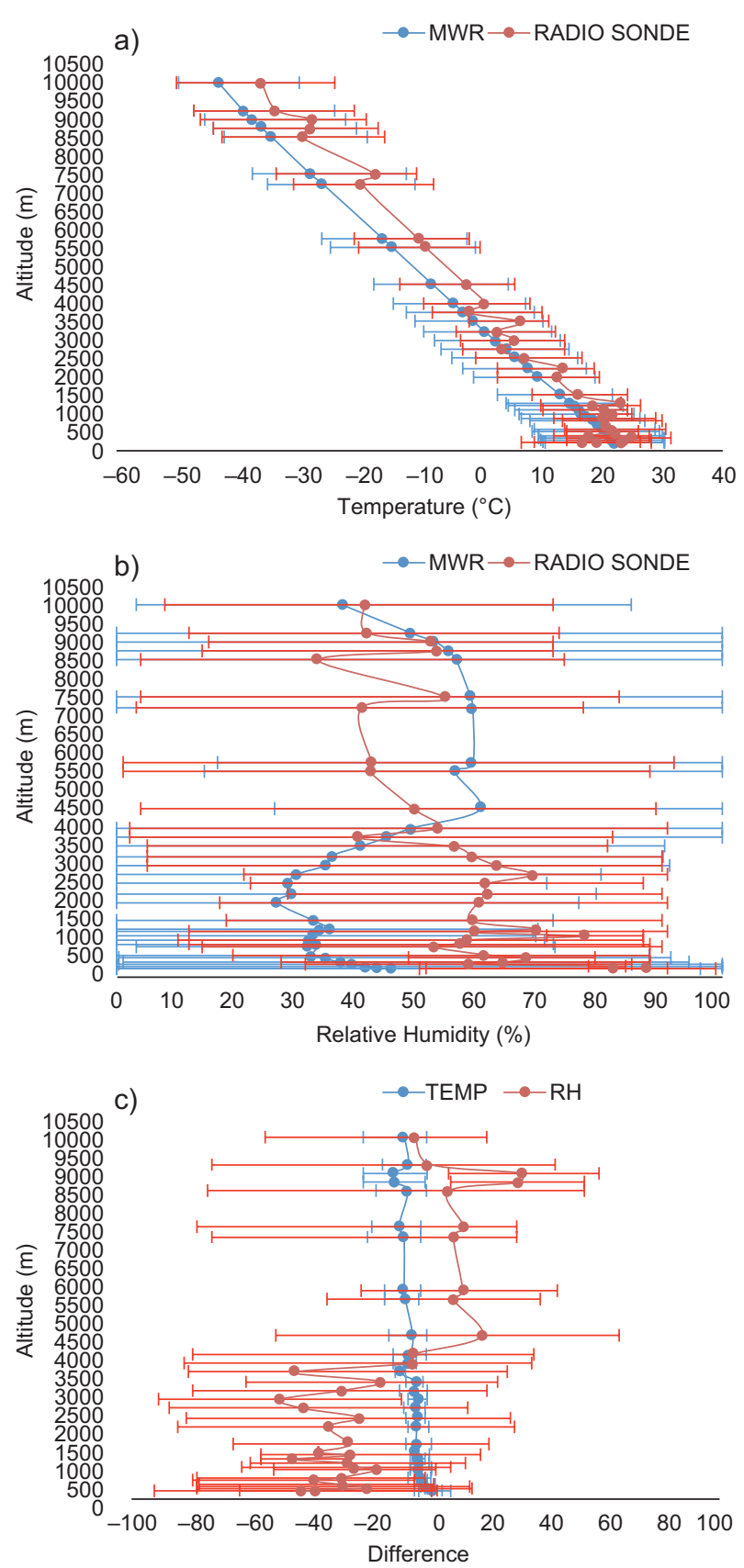

Fig. 1. 00:00 UTC composite profiles along with standard deviation observed for all cases under study. (a) Temperature). (b) Relative humidity (\%). (c) Differences between radiosonde and MWR temperatures (blue line) and relative humidity (red line). 
a)

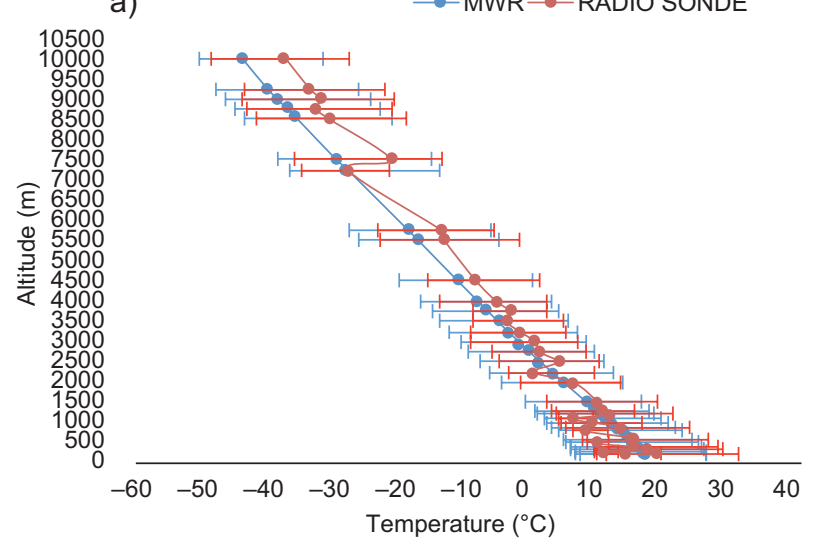

b)

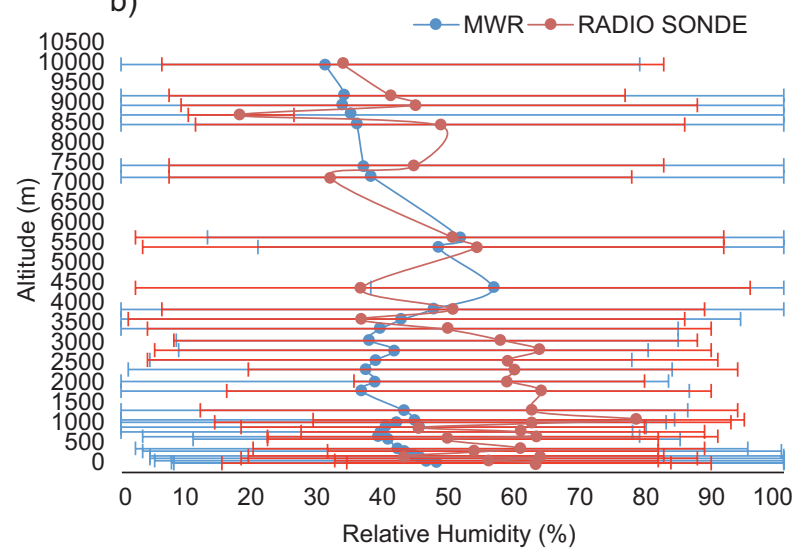

c)

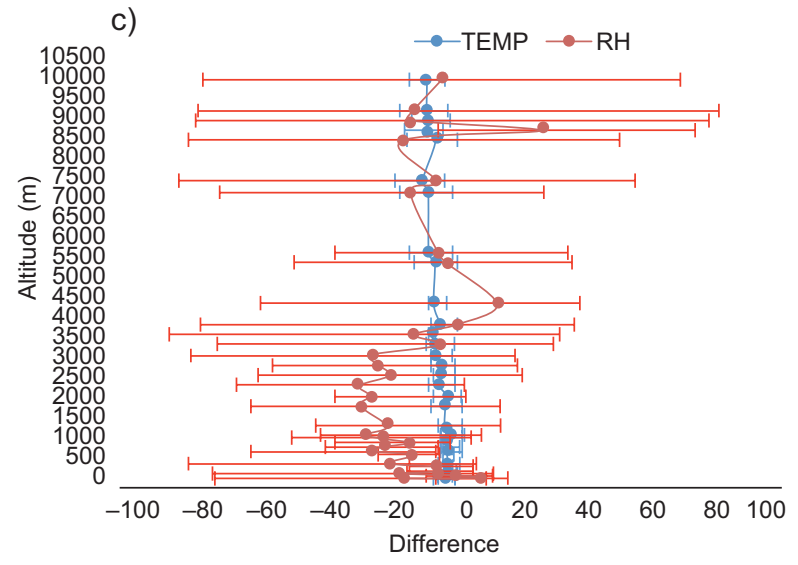

Fig. 2. 12:00 UTC composite profiles along with standard deviation observed for all cases under study. (a) Temperature). (b) Relative humidity (\%). (c) Differences between radiosonde and MWR temperatures (blue line) and relative humidity (red line).

meters above mean sea level. Temperature profiles for both 00:00 and 12:00 UTC represent the close match up to $3.5 \mathrm{~km}$ (Figs. 1a and 2a). However, temperature has a variation of $1-2{ }^{\circ} \mathrm{C}$ (RS-based temperatures are higher as compared to MWR) at middle and upper levels as shown in the difference profile of Figures 1c and $2 \mathrm{c}$. MWR profiles show a cold bias above $3.5 \mathrm{~km}$ and the trend remains the same with variations in quantity at various levels. Contrast in the $\mathrm{RH}$ profile was found to be large at different levels for both 00.00 and 12:00 UTC (Figs. 1b and 2b). Deviation is even larger at lower levels, i.e., below $3.5 \mathrm{~km}$. Figures $1 \mathrm{c}$ and $2 \mathrm{c}$ depict the difference plot of RH. It clearly shows the presence of a dry bias in the range of $30-50 \%$ up to $3.5 \mathrm{~km}$, and thereafter a wet bias of $20-30 \%$ at higher levels. The variations in $\mathrm{RH}$ were found to be higher (about 10-15\%) for the morning profiles.

\subsubsection{Variations in MWR-radiosonde profiles}

Chan and Hon (2011) established that the measurement principle of the two instruments is different (volume integral above a fixed location on the ground for radiometer vs. point measurement of a drifting balloon for radiosonde), hence there are biases and spreads of the data, but the trend was found to be identical. However, the present case study reflects that only the temperature trend of both profiles matches, whereas the $\mathrm{RH}$ profile has variations, primarily up to $3.5 \mathrm{~km}$.

\subsection{Correlation between MWR and radiosonde ba- sed indices}

Correlation and p-value (using a t-test) between MWR and RS-based indices were calculated separately for 00:00 and 12:00 UTC profiles (Table II). A total of nine indices/parameters of zenith scan of MWR and nearest RS station have been studied. The results showed that none of these indices are correlated for the 00:00 UTC profile. However, moderate correlation in KI, VTT, TTI, MEAN_RH (950-700 hPa) and TEMP_DIFF (950-700 hPa) were observed for the 12:00 UTC profile. The scattered plots of one of the least (KI for 00:00 UTC) and best (TEMP_DIFF between 950 and $700 \mathrm{hPa}$ for 12:00 UTC) correlated indices are depicted in Figure 3, which the high variation of parameters derived form MWR and radiosonde profiles are confirmed. The best-fit line along with the equation are shown over the plots; however, it cannot be used for forecasting purposes. 
Table II. Correlation between MWR- and radiosonde-based indices at 00:00 and 12:00 UTC.

\begin{tabular}{cccc}
\hline No. & Indices & $\begin{array}{c}\text { Correlation values }(\mathrm{R}) / \mathrm{p} \text {-value } \\
(00: 00 \mathrm{UTC})\end{array}$ & $\begin{array}{c}\text { Correlation values }(\mathrm{R}) / \mathrm{p} \text {-value } \\
(12: 00 \mathrm{UTC})\end{array}$ \\
\hline 1 & KI & $0.09 / 0.79$ & $0.49 / 0.12$ \\
2 & CTT & $0.09 / 0.79$ & $0.25 / 0.45$ \\
3 & VTT & $0.16 / 0.63$ & $0.49 / 0.12$ \\
4 & TTI & $0.16 / 0.63$ & $0.36 / 0.27$ \\
5 & MEAN_RH (950-700 hPa) & $0.16 / 0.63$ & $0.49 / 0.12$ \\
6 & RH_FL & $0.04 / 0.90$ & $0.16 / 0.63$ \\
7 & TEMP_DIFF (950-700 hPa) & $0.04 / 0.90$ & $0.81 / 0.002$ \\
8 & TEMP_DIFF (700-400 hPa) & $0.09 / 0.79$ & $0.16 / 0.63$ \\
9 & TEMP_DIFF (400-300 hPa) & $0.16 / 0.63$ & $0.16 / 0.63$ \\
\hline
\end{tabular}

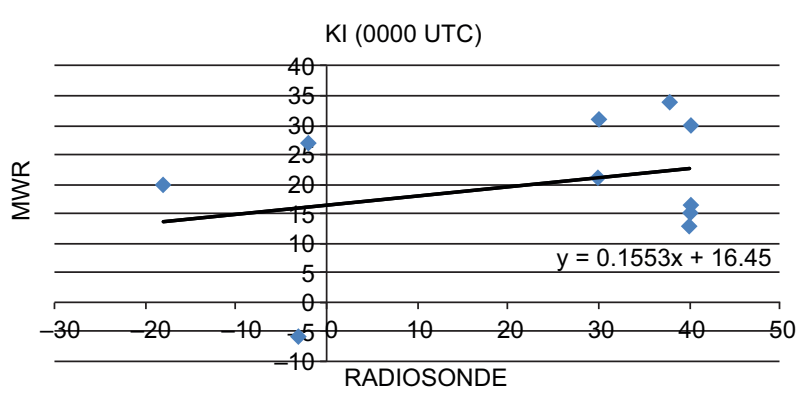

TEMP_DIFF (950-700 hPa) / 1200 UTC

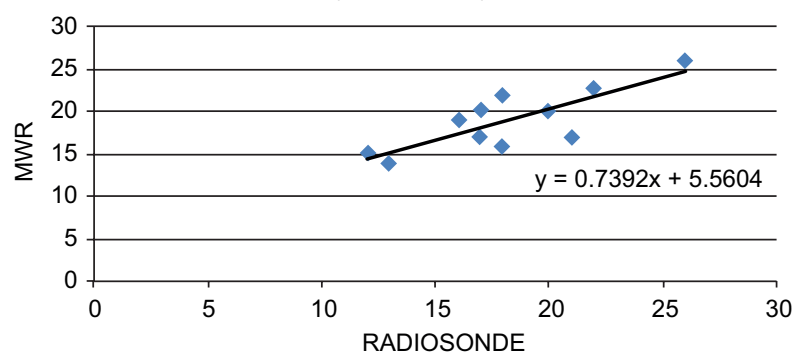

Fig. 3. Scatter plot of MWR-radiosonde indices generated with 00:00 and 12:00 UTC profiles. (a) KI (in ${ }^{\circ} \mathrm{C}$ ) at 00:00 UTC with one of the lower correlations (0.09). (b) Temperature differences between 950 and $700 \mathrm{hPa}\left(\right.$ in ${ }^{\circ} \mathrm{C}$ ) at 12:00 UTC with best correlation (0.81).

3.3 Case study of thunderstorm over Delhi on February 17, 2009

\subsubsection{Cases under study}

A total of eight thunderstorm cases over Delhi have been studied. An elaborated analysis of a thunderstorm event occurred on February 7, 2019 has been covered in this section.

\subsubsection{Weather sequence}

Cyclonic storms associated with the mid latitude Subtropical Westerly Jet (SWJ), referred to as Western Disturbances (WDs) play a critical role in the meteorology of the Indian subcontinent. WDs embedded in the southward propagating SWJ produce extreme precipitation over northern India and are further enhanced over the Himalayas due to orographic land-atmosphere interactions (Dimri et al., 2015). A similar type of extra-tropical system moved across the northern region on February 7, 2019. INSAT-3D (IR1) satellite images of that day from 10:30 to 13:30 UTC (Fig. 4) depict the presence of multi-layered clouding embedded with intense convection in isolation over Delhi and adjoining area. METAR reports of IGI airporta in Delhi reveal the commencement of thunderstorm activity with effect from 11:30 UTC.

\subsubsection{Movement of convective cells}

The MWR location is approximately $10 \mathrm{~km}$ (aerial) southwest of the IGI airport, Delhi. The Max (z) product of DWR, installed at the airport, is shown in Figure 5. It clearly indicates the presence of a convective cell southwest of the MWR station at 10:32 UTC with vertical extent up to $6 \mathrm{~km}$. This cell can be seen overhead at 11:02 UTC with a new one developing in southwest direction at a distance of $20 \mathrm{~km}$. A second convective cell reached overhead by 12:32 UTC. Reflectivity on both occasions was $>$ $57.0 \mathrm{dBZ}$, which substantiates the presence of intense convection. 

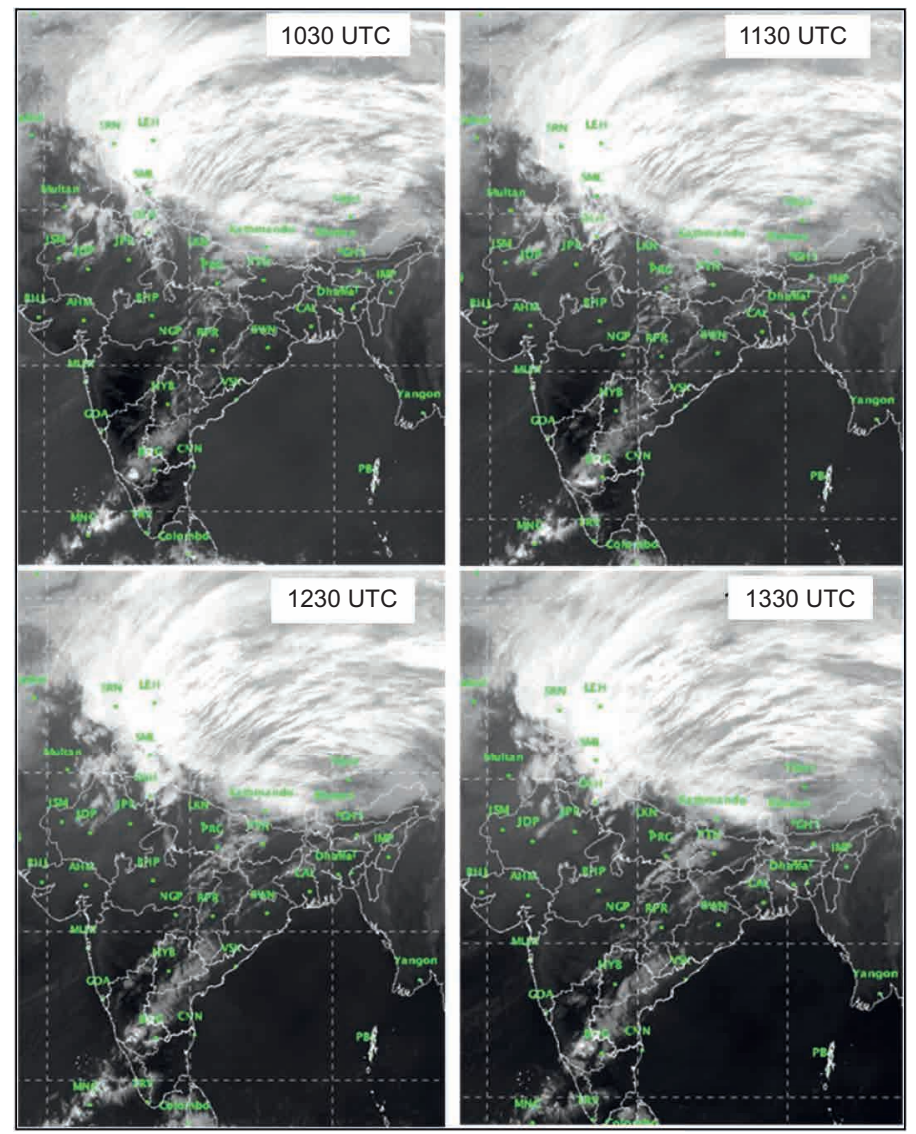

Fig. 4. INSAT-3D (IR1) images of February 7, 2019 from 10:32 to 13:02 UTC.

\subsubsection{MWR profile of the episode}

Pre- and post-convective environment of February 7, 2019 was also studied in the light of MWR based profile. Timeline of temperature, $\mathrm{RH}$ and vapor density variations are depicted in Figure 6, where it is clearly shown that vertical temperatures were insensitive to the pre-convective environment and sharp changes could only be seen during the actual occurrence of the weather event (11:30 UTC). High $\mathrm{RH} \%$ (>90\%) was seen at lower levels (up to $1.5 \mathrm{~km}$ ) at 09:00 UTC and the same reduced thereafter until the time of occurrence. RH was seen increasing gradually from 09:00 UTC onwards between 3 and $6 \mathrm{~km}$. However, the quantity reduced significantly to $70 \%$ just prior to the occurrence. Absolutely saturated atmosphere is depicted during the time of occurrence of both the spells. A gradual increase of vapor density was also observed prior to the occurrence, wherein the values reached from 1 to $7 \mathrm{~g} \mathrm{~m}^{-3}$ in between 2 and $3 \mathrm{~km}$ levels. At lower levels the gradient was higher, with an increase of approximately 8.0 units. Maximum contours in the values coincide with the time of occurrence. Vapor density is the only parameter showing significant changes in pre-convective environment. The rise in this feature is indicative of the increase in saturated water content at different levels of the atmosphere which contributed to the convective build-up.

\subsubsection{Lightning counts and MWR indices}

The case was further analyzed by calculating and studying the variation of MWR-based indices. For that purpose, pre- and post-convective hourly values of the various indices/parameters have been plotted against the total number of lightning flashes sensed by the IAF LDS within $50 \mathrm{~km}$ of the MWR location. Figure 7 shows the variation in different indices with respect to number of lightning flashes on the 


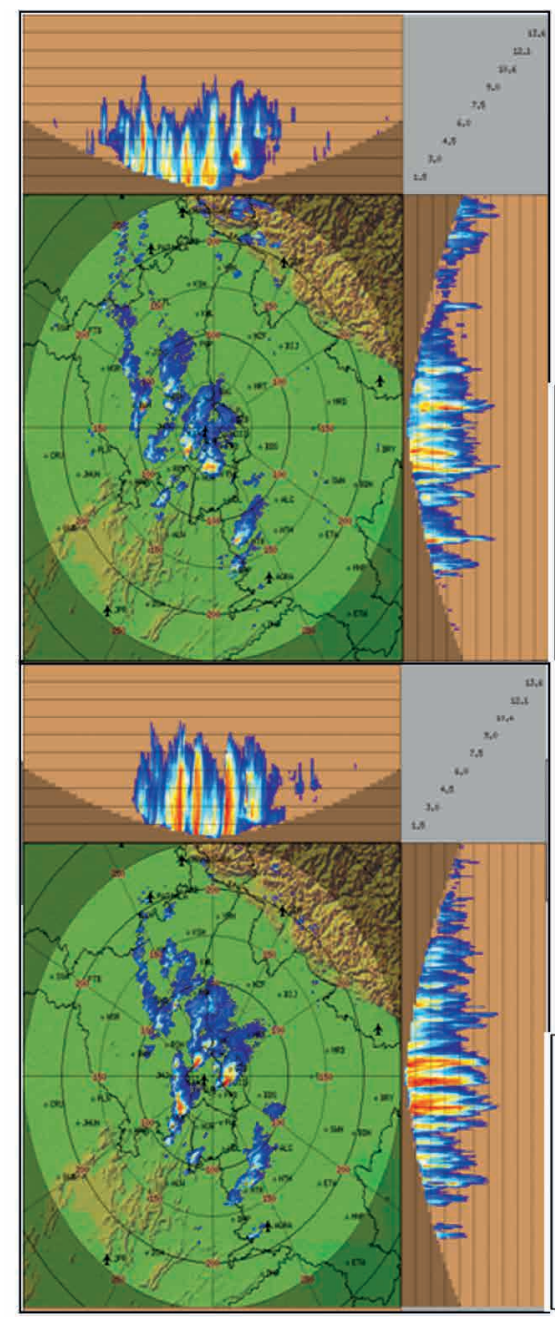

Delhi

Max with panels

Max_Z

Task: IMD-B

Min Hgt: $0.0 \mathrm{Km}$

Max Hgt: $15.0 \mathrm{Km}$

Max Range:

$250 \mathrm{Km}$

10:32:30Z

7 Feb 2019 TC

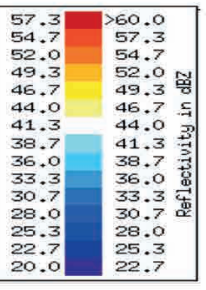

\section{Delhi}

Max with panels

Max_Z

Task: IMD-B

Min Hgt: $0.0 \mathrm{Km}$

Max Hgt: $15.0 \mathrm{Km}$

Max Range:

$250 \mathrm{Km}$

11:32:29Z

7 Feb 2019 TC

\begin{tabular}{|c|c|}
\hline \multirow{2}{*}{\multicolumn{2}{|c|}{57.3}} \\
\hline & 57.3 \\
\hline & \\
\hline 49.3 & 52.0 \\
\hline 46.7 & 49.3 \\
\hline 44.0 & 46.7 \\
\hline 41.3 & 44.0 \\
\hline 38.7 & 41.3 \\
\hline 36.0 & 38.7 \\
\hline 33.3 & 36.0 \\
\hline 30.7 & 33.3 \\
\hline 28.0 & 30.7 \\
\hline 25.3 & 28.0 \\
\hline 22.7 & $25 \cdot 3$ \\
\hline & \\
\hline
\end{tabular}

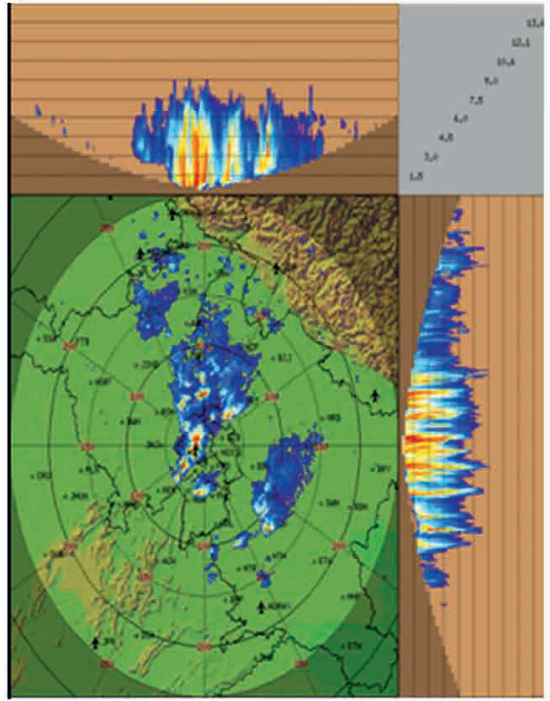

\section{Delhi}

Max with panels

Max_Z

Task: IMD-B

Min Hgt: $0.0 \mathrm{Km}$

Max Hgt: $15.0 \mathrm{Km}$

Max Range:

$250 \mathrm{Km}$

12:32:29Z

7 Feb 2019 TC

\begin{tabular}{|c|c|}
\hline 57.3 & $>60.0$ \\
\hline 54.7 & 57.3 \\
\hline 49.3 & 52.0 \\
\hline 46.7 & 49.3 명 \\
\hline 44.0 & $46.7 \subseteq$ \\
\hline 41.3 & $44.0=3$ \\
\hline 38.7 & $41.3=$ \\
\hline 36.0 & 38.7 \\
\hline 33.3 & 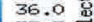 \\
\hline 30.7 & 33.3 \\
\hline 28.0 & 30.7 \\
\hline 25.3 & 28.0 \\
\hline 22.7 & 25.3 \\
\hline 20.0 & 22.7 \\
\hline
\end{tabular}
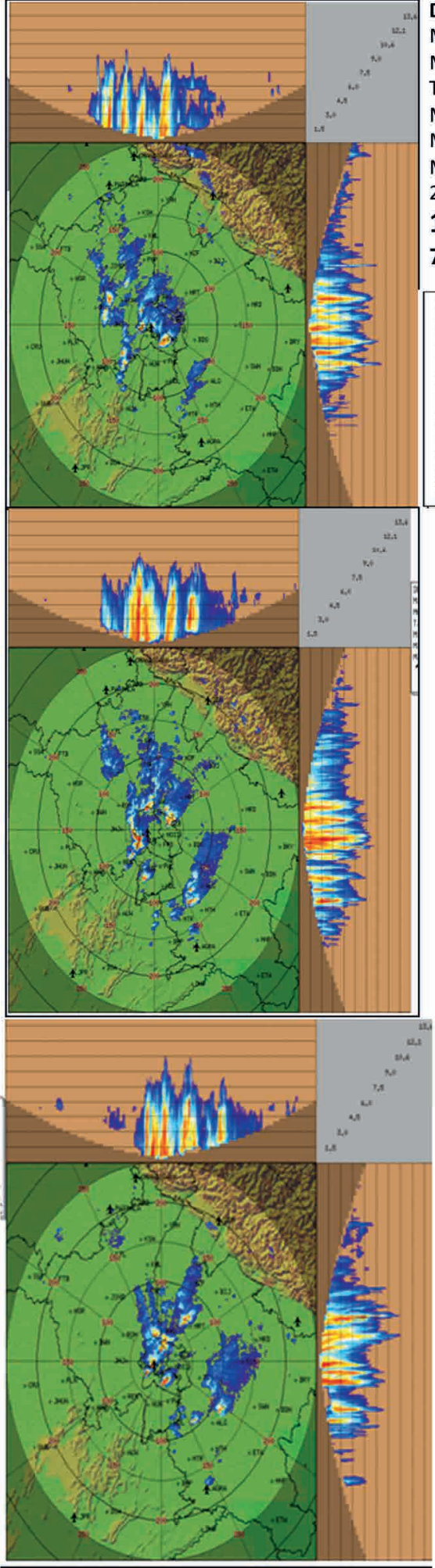

Delhi

Max with panels

Max_Z

Task: IMD-B

Min Hgt: $0.0 \mathrm{~km}$

Max Hgt: $15.0 \mathrm{Km}$

Max Range:

$50 \mathrm{Km}$

11:02:29Z

7 Feb 2019 TC

\begin{tabular}{|c|c|}
\hline $\begin{array}{l}57.3 \\
54.7 \\
52.0 \\
49.3 \\
46.7 \\
44.0 \\
41.3 \\
38.7 \\
36.0 \\
33.3 \\
30.7 \\
28.0 \\
25.3 \\
30.7\end{array}$ & $\begin{array}{l}41.3 \\
38.7 \\
36.0 \\
33.3 \\
30.7 \\
28.0 \\
25.3 \\
22.7\end{array}$ \\
\hline
\end{tabular}

\section{Delhi}

Max with panels

Max_Z

Task: IMD-B

Min Hgt: $0.0 \mathrm{Km}$

Max Hgt: $15.0 \mathrm{Km}$

Max Range:

$250 \mathrm{Km}$

12:02:29Z

7 Feb 2019 TC

\begin{tabular}{|c|c|}
\hline 57.3 & 760.0 \\
54.7 & 57.3 \\
52.0 & 54.7 \\
49.3 & 52.0 \\
45.7 & 49.3 \\
44.0 & 46.7 \\
41.3 & 44.0 \\
38.7 & 41.3 \\
36.0 & 38.7 \\
33.3 & 36.0 \\
30.7 & 33.3 \\
28.0 & 30.7 \\
25.3 & 28.0 \\
22.7 & 25.3 \\
20.0 & 22.7 \\
\hline
\end{tabular}

Delhi

Max with panels

Max_Z

Task: IMD-B

Min Hgt: $0.0 \mathrm{Km}$

Max Hgt: $15.0 \mathrm{Km}$

Max Range:

250Km

13:02:30Z

7 Feb 2019 TC

\begin{tabular}{|l|l|}
\hline 57.3 & $>60.0$ \\
54.7 & 57.3 \\
52.0 & 54.7 \\
49.3 & 52.0 \\
46.7 & 49.3 \\
44.0 & 46.7 \\
41.3 & 44.0 \\
38.7 & 41.3 \\
36.0 & 38.7 \\
33.3 & 36.0 \\
30.7 & 33.3 \\
28.0 & 30.7 \\
25.3 & 28.0 \\
22.7 & 25.3 \\
20.0 & 22.7 \\
\hline
\end{tabular}

Fig. 5. DWR Max (z) products of Delhi Indira Gandhi International Airport of February 7, 2019 from 10:32 to 13:02 UTC. 

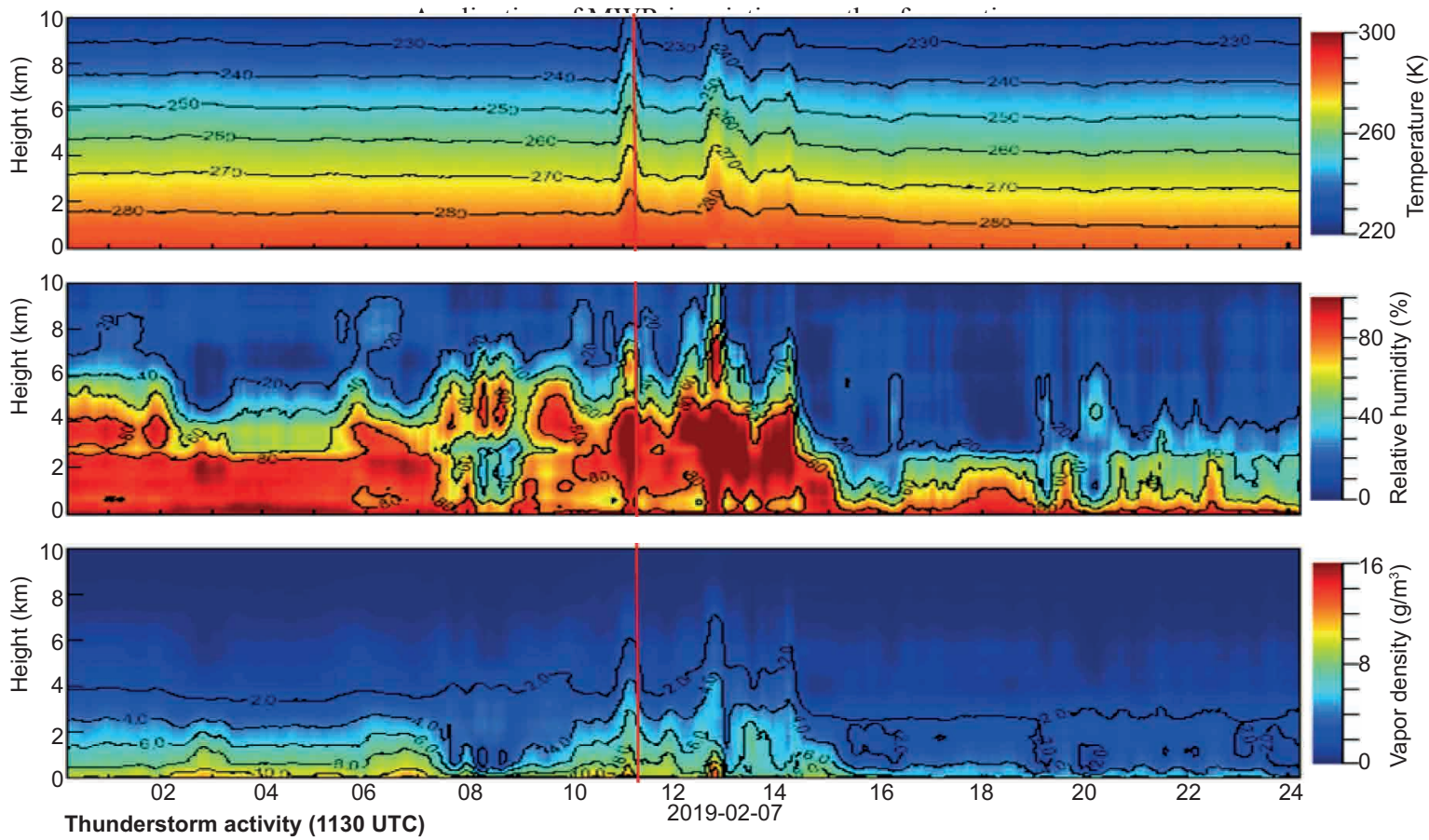

Fig. 6. MWR-generated profile for February 7, 2019 displaying variations in temperature, relative humidity and vapor density regarding the genesis of thunderstorm.

a)

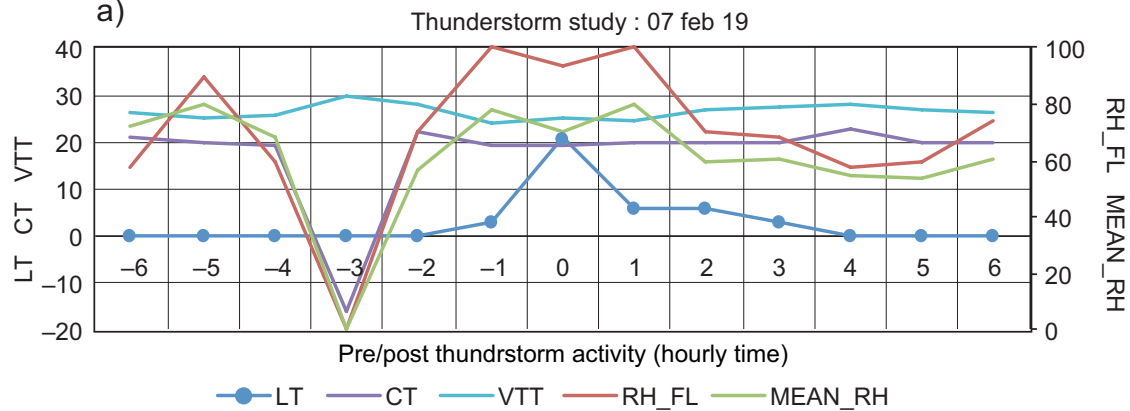

b) Thunderstorm study : 07 feb 19

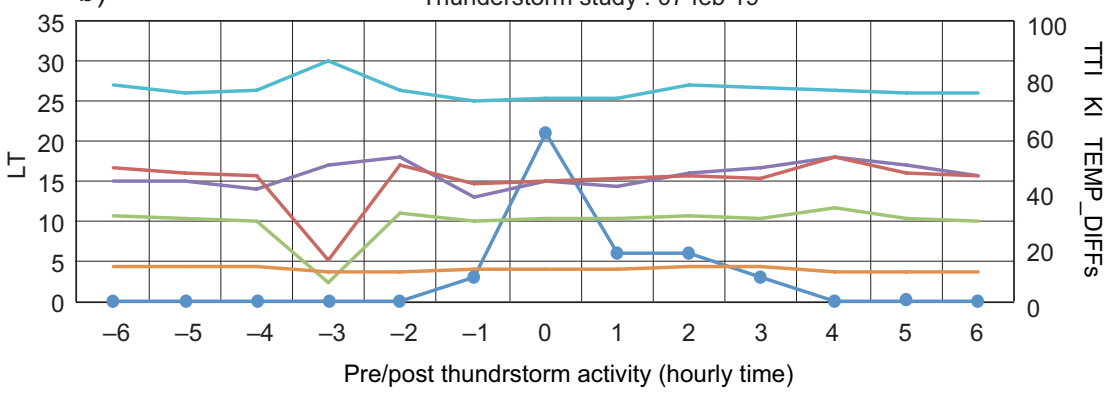

$\rightarrow-$ LT —TEMP_DIFF(950-700hPa) —TEMP_DIFF(700-400hPa)

- TTI - KI —TEMP_DIFF(400-300hPa)

Figure 7. Time series plot of various indices and parameters generated through the MWR profile on February 7, 2019 vs. the count of lightning. $\mathrm{X}$-axis shows the $\pm 6 \mathrm{~h}$ of post/pre convective phase where $\mathrm{x}=0$ depicts the time of maximum thunderstorm activity. (a) The left $\mathrm{Y}$ axis denotes the variation of CT, VT and lightning count and the right Y-axis denotes the variation of RH at freezing level (RH_FL), mean relative humidity. (b) The left Y-axis denotes the variation of lightning count and the right Y-axis denotes variations of TTI, KI and temperature differences at various levels (TEMP_DIFFs). 
day of occurrence. Left Y-axis depicts the number of lightning flashes, CT and VTT and right Y-axis depicts the variation of RH, TTI, KI and temperature differences for various levels. X-axis represents the timeline where " 0 " is the time of occurrence (11:30 UTC) and " \pm " values depict pre- and post-convective hours, respectively. Analysis portrays the significant increase in $\mathrm{RH} \%$ at freezing level and between $950-700 \mathrm{hPa}$, wherein the values reach to $98 \%$ as compared to nil, recorded $3 \mathrm{~h}$ prior to occurrence. Decreasing trend in the CT, VTT (Fig. 7a), TTI and $\mathrm{KI}$ (Fig. 7b) indices were noticed prior to the time of occurrence of thunderstorm. Feeble fall $\left(\sim 3^{\circ} \mathrm{C}\right)$ in the temperature difference of 950 and $700 \mathrm{hPa}$ (Fig. 7b) level was recorded $1 \mathrm{~h}$ prior to the occurrence of thunderstorm. Temperature variations in middle (700-400 hPa) and upper (400-300 hPa) levels were found to be insignificant (Fig. 7b).

\subsection{Superepoch analysis}

\subsubsection{Time lag analysis}

Madhulatha et al. (2013) suggested the superepoch analysis technique to obtain a composite picture of all thunderstorm events vis-à-vis the variation of different indices/parameters on the time series. To examine the temporal variations of various thermal indices lagged composite of all the nine parameters are calculated and depicted in Figure 8. The thunderstorm time of occurrence is considered as lag 0 and lag -6 corresponds to the environment $6 \mathrm{~h}$ before the thunderstorm. Similarly, lag +6 denotes the environment $6 \mathrm{~h}$ after the occurrence of the thunderstorm. In the current depiction, storm occurrence in considered as zero.

\subsubsection{Amalgamated depiction of thunderstorm cases}

For this technique, nine parameters were calculated for all the eight thunderstorm cases. Pre- and post-
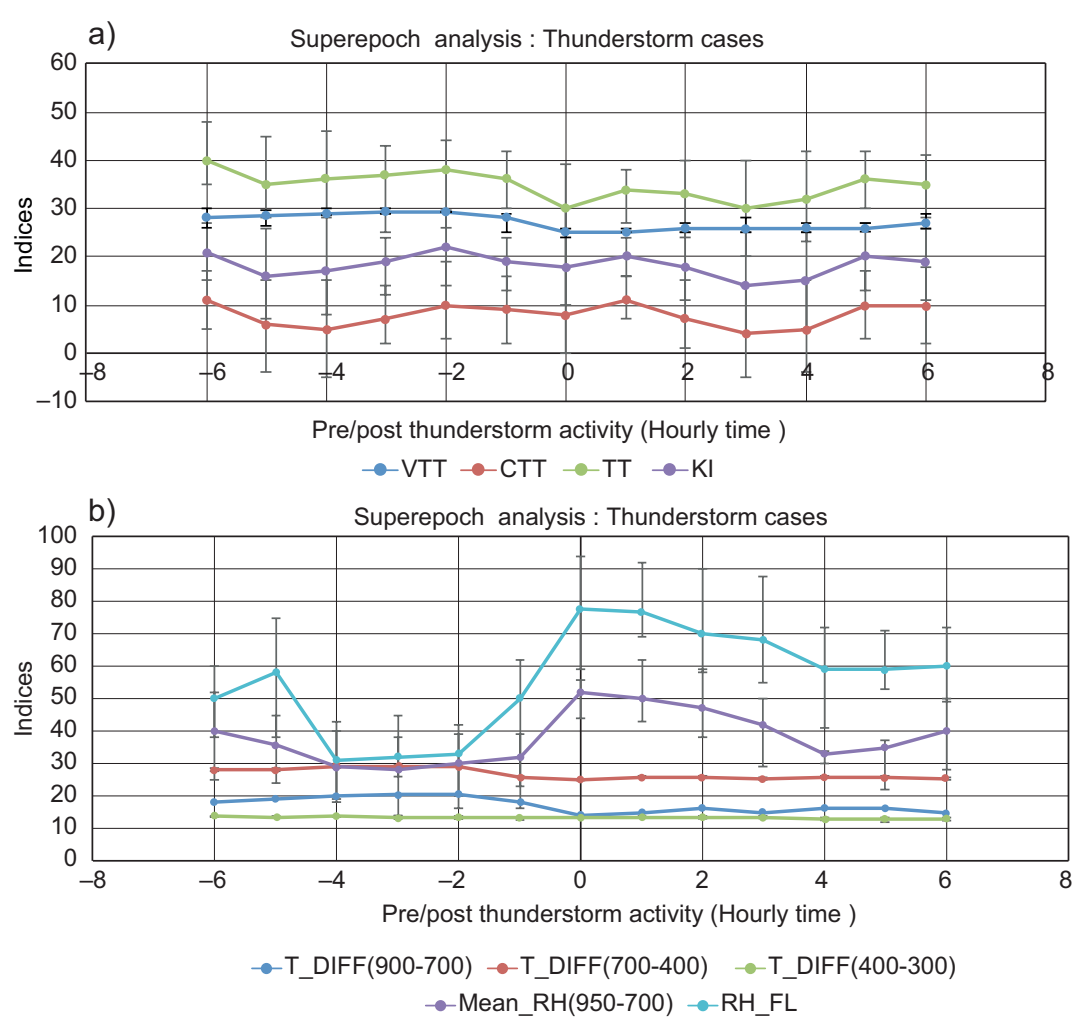

Fig. 8. Superepoch analysis of nine indices/parameters for eight thunderstorm cases, where $\mathrm{x}=0$ depicts the time of maximum thunderstorm activity. (a) VTT, CTT, TT, and KI. (b) T_DIFF (900-700 hPa), T_DIFF (700-400 hPa), T_DIFF (400-300 hPa), MEAN_RH (950-700 hPa), and RH_FL. 
environment conditions were superimposed to give a composite picture of each case and thereafter all the cases were merged to present an average variation in the indices/parameters. The average variation is depicted in bold lines in Figure 8, whereas the vertical bars showcase the range of deviation.

\subsubsection{Thunderstorm nowcasting}

Rajeevan et al. (2012) mention that the variation of composite time series of thermodynamical parameters can explain the prerequisites necessary for the genesis of thunderstorm activity. A similar concept has been implemented in the superepoch analysis, where the MWR based indices/parameters are studied to enable the nowcasting of thunderstorm events. VTT remained almost constant with a value of $28^{\circ} \mathrm{C}$ (Fig. 8a) prior to the thunderstorm occurrence. The CTT, TT and KI indices (Fig. 8a) showed sinusoidal patterns with a marginal fall prior to the occurrence. During the time of occurrence, $\mathrm{KI}$ was about $20{ }^{\circ} \mathrm{C}$, which is very low as compared to $42^{\circ} \mathrm{C}$ as observed by Madhulatha et al. (2013). A lapse rate in the $900-700$ and $700-400 \mathrm{hPa}$ (Fig. 8b) layers was of 1 and $3{ }^{\circ} \mathrm{C}$, respectively. However, a feeble variation of $0.1{ }^{\circ} \mathrm{C}$ was seen in the lapse rate of $400-300 \mathrm{hPa}$ (Fig. $8 \mathrm{~b}$ ). The other two parameters that displayed gradual variation four hours prior to the occurrence were mean $\mathrm{RH}$ between 950 and $700 \mathrm{hPa}$ (Fig. 8b) and RH at freezing level (Fig. 8b). The rise in $\mathrm{RH}$ at freezing level was close to $36 \%$ whereas that of mean RH between 950 and $700 \mathrm{hPa}$ was almost $20 \%$.

\subsubsection{Superepoch analysis of fog events}

Superepoch analysis was also applied to three cases of dense fog over Delhi, where the visibility dropped to zero in the morning hours (Fig. 9). However, the studied parameters were related to moisture and temperature variations at the lower levels (between 200 and $500 \mathrm{~m}$ ) only. A marginal rise of the order of $0.25^{\circ} \mathrm{C}$ in the lapse rate between 500 and $200 \mathrm{~m}$ was noticed prior to the occurrence of fog. Total vapor pressure in the similar levels was almost constant with a value of $40 \mathrm{~g} \mathrm{~m}^{-3}$. Nil variation was noticed in total liquid water with values close to $0.3 \mathrm{~g} \mathrm{~m}^{-3}$. A gradual increase in mean $\mathrm{RH}$ was recorded at the lower levels with a variation of approximately $22 \%$.

\section{Inferences and conclusion}

The main objective of this study was to analyze the use of a ground based MWR for aviation weather forecasting in the IAF. For this purpose, data of the MWR were first validated using an RS for the similar time period. The results showed that the MWR and RS temperature profiles had minimal variations below $3.5 \mathrm{~km}$ for both 00:00 and 12:00 UTC. However, a moderate deviation was noted at mid and higher levels.

The variation in $\mathrm{RH}$ profile was noticed with a dry bias at lower levels and a wet bias at middle and higher levels. It was even larger at 00:00 UTC, which means that MWR-generated profiles (especially at 00:00 UTC) are significantly different from RS profiles. Also, a weak correlation and a high p-value between most of the datasets shows a large variation in derived parameters of the MWR and RS profiles.

Hence, the threshold values of indices or parameters developed with the studies of radiometer data cannot be explicitly implemented for forecasting through MWR profiles. Real time inputs received from MWRs should not be used isolated. These

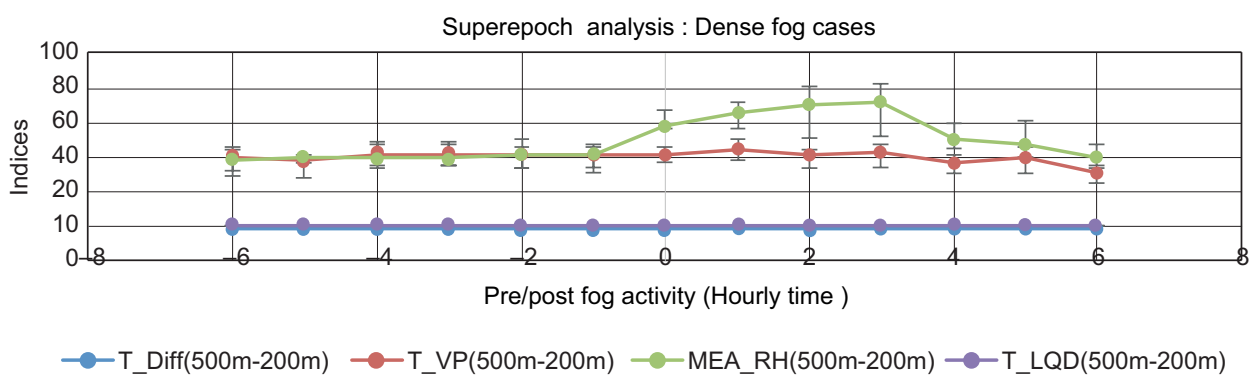

Fig. 9. Superepoch analysis of four parameters for three dense fog cases, where $\mathrm{x}=0$ depicts the time of maximum intensity of fog. 
indices need to be correlated with local forecasting suggestions and thereafter be utilized for nowcasting purposes. These huge variations may be attributable to the neural network technique and the quality of historical data used to generate the MWR profile from raw data of brightness and temperature. After the neural upgrade of MWR, the profile sensitivity needs to be established vs. thunderstorm and fog events. Refinements of the threshold values of thermodynamic indices for MWR-based prediction may also be carried out on large historical datasets.

Similarly, correlation between different indices generated through MWR and RS profiles were calculated. The results showed that parameters of 00:00 UTC have no correlation. However, a total of five parameters showed moderate correlation for 12:00 UTC profiles, which shows that $\mathrm{RH} \%$ variation has a profound impact on most of the indices and they cannot be implemented for nowcasting purpose in isolation.

As per Madhulatha et al. (2013), the superepoch analysis suggested that many thermodynamic parameters, lower-level RH, stability index at different levels, and lapse rate of equivalent potential temperature exhibited useful signals at least $3 \mathrm{~h}$ before the storm occurrence. Their analysis showed sharp changes in the thermodynamic parameters associated with storms. There are appreciable differences in the variations between thunderstorm and non-thunderstorm cases. However, in the present superepoch analysis most of the parameters under study remain insensitive prior to the occurrence of a severe weather phenomenon. At the same time, standard errors were huge. Parameters like total liquid, temperature difference, and total vapor density at 500-200 m gave no indication of dense fog events. Steep variation in the MWR profiles for similar weather makes it difficult for the forecaster to select any reliable nowcasting indices to predict thunderstorm and dense fog events.

Atmospheric instabilities, mainly convection, depend on temperature distribution and moisture availability (Leena, 2015), which are measured at very high resolution using MWR. However, based on the present study it can be inferred that MWR can only be utilized as an observation tool. Due to its inherent sources of error, MWR profiles cannot be exploited for the nowcasting purpose. There could be multiple reasons for this outcome of the study, being the most noticeable the difference between MWR and RS techniques for retrieval/observation of parameters. However, the results may vary if a greater number of cases are studied, a better neural network is treated and also the off-zenith profiles of MWR are considered for different geographical locations of the country.

\section{Acknowledgments}

The authors are extremely grateful to Air Vice Marshal Dr. Sanjay Tyagi, Assistant Chief of Air Staff (Meteorology), Indian Air Force, for providing data, professional guidance and motivation during the study period. The authors sincerely thank Air Commodore (Meteorology) Dr. JK Sahu for the encouragement and support for improving the manuscript. The authors are also thankful to Director General, Indian Meteorological Department (IMD) for providing radiosonde data. The authors acknowledge the maintenance services provided by Radiometrics Corporation.

\section{Data availability}

Due to the sensitive nature of the data used in this study, authors are not able to share the research data.

\section{References}

Chan PW. 2009. Performance and application of a multi-wavelength, ground-based microwave radiometer in intense convective weather. Meteorologische Zeitschrift 18: 253-265. https://doi.org/10.1127/09412948/2009/0375

Chan PW, Hon KK. 2011. Application of ground-based, multichannel microwave radiometer in the nowcasting of intense convective weather through instability indices of the atmosphere. Meteorologische Zeitschrift 20: 431-440. https://doi.org/10.1127/09412948/2011/0276

Dimri AP, Niyogi D, Barros AP, Ridley J, Mohanty UC, Yasunari T, Sikka DR. 2015. Western disturbances: A review. Reviews of Geophysics 53: 225-246. https:// doi.org/10.1002/2014RG000460

Hering AM, Morel C, Galli G, Sénési S, Ambrosetti P, Boscacci M. 2004. Nowcasting thunderstorms in the alpine region using radar based adaptive thresholding 
scheme. In: 3rd European Conference on Radar in Meteorology and Hydrology (ERAD), Visby, Sweden, September 6-10. Available at: http://www.copernicus. org/erad/2004/online/ERAD04_P_206.pdf (accessed on April 10, 2021).

Lee OSM. 2007. Forecast of strong gust associated with thunderstorms based on data from radiosonde ascents and automatic weather stations. In: 21 st Guangdong-Hong Kong-Macao Technical Seminar on Meteorological Science and Technology, Hong Kong. Leena PP, Dani KK, Nath A, Sanap SD, Pandithurai G, Anil Kumar V. 2015. Validation of ground-based microwave radiometer data and its application in verifying atmospheric stability over Mahbubnagar during 2011 monsoon and post-monsoon seasons. International Journal of Remote Sensing 36: 2920-2933. http://doi. org/10.1080/01431161.2015.1051632

Madhulatha A, Rajeevan M, Madineni VR, Bhate J, Naidu CV. 2013. Nowcasting severe convective activity over southeast India using ground-based microwave radiometer observations. JGR Atmospheres 118: 1-13. https://doi.org/10.1029/2012JD018174

Rajeevan M, Madhulatha A, Rajasekhar M, Bhate J, Kesarkar A, Apparao BV. 2012. Development of a perfect prognosis probabilistic model for prediction of lightning over south-east India. Journal of Earth System Science 121: 355-371. https://doi.org/10.1007/s12040-012-0173-y

Rose T, Crewell S, Löhnert U, Simmer C. 2005. A network suitable microwave radiometer for operational monitoring of the cloudy atmosphere. Atmospheric Research 75: 183-200. https://doi.org/10.1016/j.atmosres.2004.12.005

Venkat Ratnam M, Durga Santhi Y, Rajeevan M, Vijaya Bhaskara Rao S. 2013. Diurnal variability of stability indices observed using radiosonde observations over a tropical station: Comparison with microwave radiometer measurements. Atmospheric Research 124: 21-33. https://doi.org/10.1016/j.atmosres.2012.12.007 